\title{
Brexpiprazol
}

\section{Miloslav Kopeček}

\section{Národní ústav duševního zdraví Klecany a Klinika psychiatrie 3. LF UK Praha}

Brexpiprazol je antipsychotikum druhé generace, které je parciálním agonistou serotoninových 5-HT1A a dopaminových D2 receptorů a antagonistou serotoninových 5-HT2A receptorů. Brexpiprazol byl účinný v léčbě schizofrenie v dávkách 2-4 mg/d a také jako prídavek $k$ antidepresivu v léčbě rezistentní depresivní poruchy v dávkách 2-3 mg/d. Dle Evropské lékové agentury je schválen pro léčbu schizofrenie dospělých jedinců, ale není schválen pro přídatnou léčbu $\mathrm{k}$ antidepresivům v léčbě depresivní poruchy jako v USA. Nejčastějším nežádoucím účinkem je akatizie a zvýšení hmotnosti. Výhodou léku je podávání $1 \times$ denně, dobrá snášenlivost a absence nežádoucích účinků na prodloužení QTc intervalu i sexuální funkce.

Klíčová slova: antipsychotika, brexpiprazol, depresivní porucha, parciální dopaminový agonista, schizofrenie.

\section{Brexpiprazole}

Brexpiprazole is a second generation antipsychotic that works as a partial agonist at serotonin 5-HT1A and dopamine D2 receptors and an antagonist at serotonin 5-HT2A. Brexpiprazole showed efficacy for the treatment of schizophrenia in the range of 2 to $4 \mathrm{mg} / \mathrm{d}$ and as an adjunct to antidepressant therapy in major depressive disorder when dosed at 2 to $3 \mathrm{mg} / \mathrm{d}$. It has European Medicines Agency approval for monotherapy treatment of adult schizophrenia but has not approval for adjunctive treatment to antidepressants for MDD as in USA. The most common 
adverse effects include akathisia and weight gain. Advantages of brexpiprazole include once-daily dosing, good tolerability, and lack of effect on QTc interval and sexual function.

Key words: antipsychotic, brexpiprazole, depressive disorder, partial dopamine agonist, schizophrenia.

\section{Zařazení do skupiny léků}

Brexpiprazol (Obr. 1) patří mezi antipsychotika druhé generace. $\checkmark$ ATC klasifikaci náleží mezi psycholeptika a je mu přiřazen kód N05AX16. Svým receptorovým profilem se řadí mezi parciální dopaminové agonisty (Tab. 1). Bývá také označován jako tzv. modulátor aktivity serotoninu a dopaminu (SDAM). Po aripiprazolu (1) a kariprazinu (2) jde o třetí lék ze stejné skupiny, který je nově dostupný na trhu a patří mezi novinky v léčbě schizofrenie i prídatné léčby depresivní poruchy (3).

\section{Mechanismus účinku}

Brexpiprazol je silný parciální agonista 5-HT1A receptorů a silný dopaminový D2/D3 parciální agonista s preferenční vazbou k D2 receptorům (5). Dopaminový parciální agonismus reguluje dopaminovou aktivitu. Stimuluje dopaminové D2 receptory v prípadě nedostatku dopaminu (u depresivní poruchy) a naopak blokuje dopaminové D2 receptory $\checkmark$ prípadě jeho nadbytku (u akutní psychózy)(6). Tento farmakodynamický efekt má společný s aripiprazolem i kariprazinem a liší se od ostatních antipsychotik, která jsou predevším antagonisty dopaminových D2 receptorů (Obr. 2).

Mezi důvody rozvoje této skupiny antipsychotik patří mimo účinnost také 1) nižší míra extrapyramidových (EPS) nežádoucích účinků

\section{Obr.1. Chemická struktura brexpiprazolu}

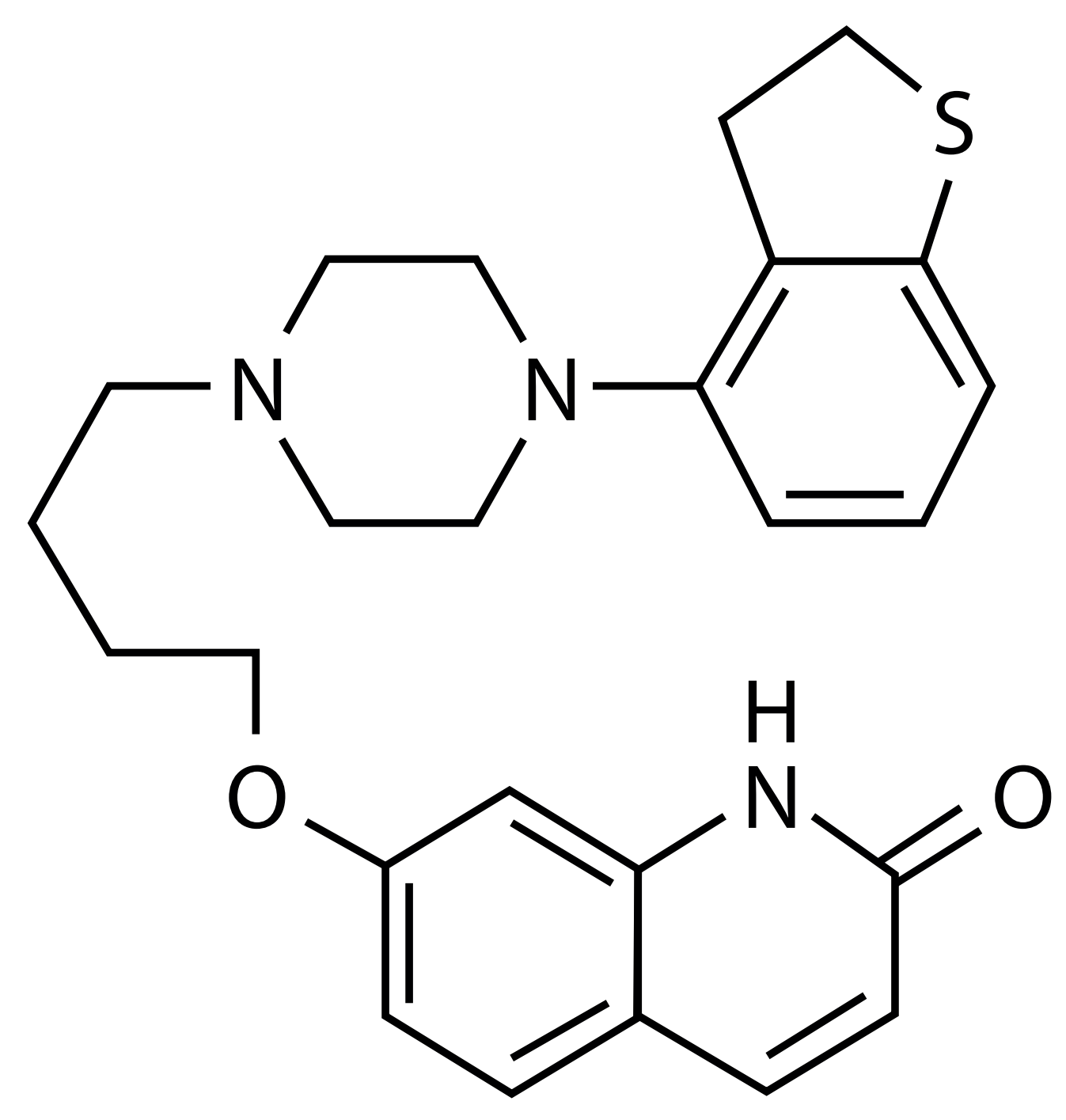


Tab. 1. Vazebné konstanty parciálních dopaminových antagonistů (brexpiprazolu, aripiprazolu a kariprazinu) k receptorům (<1 velmi vysoká, 1-5 vysoká, 5-100 střední, >100 slabá), upraveno dle (4)

\begin{tabular}{|l|c|c|c|c|c|c|c|c|c|}
\hline receptory & $\mathbf{a}_{\mathbf{1 B}}$ & $\mathbf{a}_{\mathbf{2 C}}$ & $\mathbf{D}_{\mathbf{2}}$ & $\mathbf{\mathbf { D } _ { \mathbf { 3 } }}$ & $\mathbf{M}_{\mathbf{1}}$ & $\mathbf{H}_{\mathbf{1}}$ & $\mathbf{5}-\mathbf{H T}_{\mathbf{1 A}}$ & $\mathbf{5}-\mathbf{H T}_{\mathbf{2 A}}$ & $\mathbf{5}-\mathbf{H T}_{\mathbf{2 C}}$ \\
\hline brexpiprazol & 0,17 & 0,59 & 0,30 & 1,1 & $>1000$ & 19 & 0,12 & 0,47 & 34 \\
\hline aripiprazol & 35 & 38 & 0,34 & 0,8 & $>1000$ & 61 & 1,7 & 3,4 & 15 \\
\hline kariprazin & 155 & & 0,49 & 0,085 & $>1000$ & 23 & 2,6 & 18,8 & 134 \\
\hline
\end{tabular}

Vysvětlivky: 5-HT - serotoninergní 5-HT receptor, 5-HT $T_{2 A, 2 C}$ - serotoninergní 5-HT $T_{2 A, 2 C}$ receptor, $a_{1 B}$ a $a_{2 C}$ - adrenergních alfa ${ }_{1 B}$ a alfa $a_{2 C}$ receptor, $D_{2} / D_{3}-$ dopaminový $D_{2} / D_{3}$ receptor, $H_{1}$ - histaminový receptor - podtyp $H_{1} M_{1}$ - muskarinový receptor

Obr. 2. Léky ovlivňující aktivitu dopaminu na D2 receptorech, upraveno dle (7)

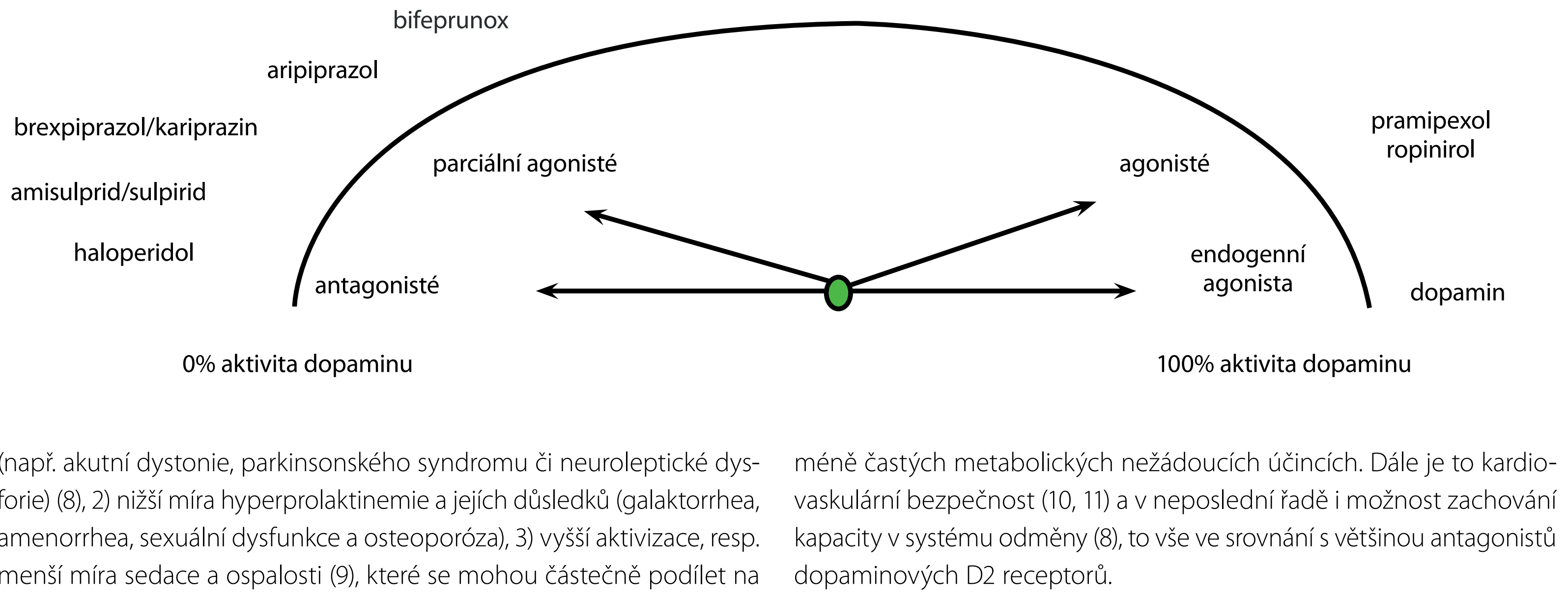


V rámci skupiny parciálních agonistů se léky mezi sebou liší svojí vnitřní aktivitou na dopaminových D2 receptorech (Obr. 2). Nejvyšší aktivitu má bifeprunox, který však nebyl schválen registračními úřady jako antipsychotikum (12). Vyšší vnitřní aktivita aripiprazolu ve srovnání s brexpiprazolem a kariprazinem je dávána do souvislosti s akatizií, insomnií, agitovaností, neklidem a nauzeou (8) pozorovanou u některých pacientů léčených aripiprazolem. Nižší vnitřní aktivita brexpiprazolu na dopaminových D2 receptorech ve srovnání s aripiprazolem by měla vést k menší frekvenci těchto nežádoucích účinků (8).

Klinický efekt blokády dopaminových D3 receptorů nebyl dosud uspokojivě objasněn. Kromě antipsychotického efektu přichází v úvahu jeho prosociální a prokognitivní působení.

Ve srovnání s aripiprazolem má brexpiprazol vyšší afinitu k 5-HT1A než dopaminovým D2 receptorům, což by mělo vést k lepšímu antidepresivnímu efektu brexpiprazolu. Preklinická data na potkanech ukazují na zlepšení kognitivních funkcí díky agonismu na 5-HT1A receptorech (13).

Brexpiprazol je dále potentní antagonista 5-HT2A a adrenergních alfa1B a alfa2C receptorů. Předchozí studie ukázaly, že blokáda 5-HT2A receptorů snižuje blokádou dopaminu způsobené extrapyramidové nežádoucí účinky. Inhibice adrenergních alfa1B receptorů může přispívat k antipsychotickému efektu, ale i k ortostatické hypotenzi či tachykardii. Inhibice adrenergních alfa2C receptorů může hrát roli v antidepresivním a prokognitivním pưsobení.

\section{Farmakokinetika}

Brexpiprazol dosahuje max. plazmatické hladiny 4 hodiny po p. o. podání a jeho dostupnost je 95\% (14). Ustálené hladiny dosahuje 10. - 12. den podávání. Absorpce není významně ovlivněna potravou. Brexpiprazol má vysoký distribuční objem ukazující na extravazální distribuci. Velmi vysoce se váže na bílkoviny (více než 99 \%). Terminální eliminační poločas po několika dnech podávání 1x denně je u mateřské látky 91 a u aktivního metabolitu DM3411 86 hodin. DM3411 tvoří v ustáleném stavu 23-48 \% hladin mateřské látky. Metabolismus probíhá v játrech prostřednictvím enzymatického systému P-450 (CYP 3A4 a 2D6). Asi $8 \%$ jedinců kavkazské rasy a 3-8 \% afro-američanů nemůže metabolizovat CYP2D6 substráty a jsou klasifikováni jako slabí metabolizéři. Protože

Tab. 2. Farmakokinetické parametry brexpiprazolu (14)

\begin{tabular}{|c|c|c|c|c|c|c|}
\hline $\begin{array}{l}\text { max. } \\
\text { sérová } \\
\text { koncent. } \\
\text { (čas) }\end{array}$ & $\begin{array}{l}\text { biol. } \\
\text { dostupnost } \\
\%\end{array}$ & $\begin{array}{l}\text { distribuční } \\
\text { objem } \\
(\mathrm{l} / \mathrm{kg})\end{array}$ & $\begin{array}{l}\text { vazba } \\
\text { na bílk. }\end{array}$ & $\begin{array}{l}\text { biol. } \\
\text { poločas }\end{array}$ & $\begin{array}{l}\text { hlavní } \\
\text { cesta } \\
\text { metabolizace }\end{array}$ & $\begin{array}{l}\text { Vylučování do mateřského } \\
\text { mléka \% dávky matky na kg }\end{array}$ \\
\hline $4 h$ & 95 & $1,56 \pm 0,42$ & > $99 \%$ & $\begin{array}{l}91 h \\
86 h^{*}\end{array}$ & $\begin{array}{l}\text { 1. CYP3A4 } \\
\text { 2. CYP2D6 }\end{array}$ & $\begin{array}{c}\text { u lidí nezjištěn, } \\
\text { u zvířat: } 1-2 x>\text { než v krvi }\end{array}$ \\
\hline
\end{tabular}

Vysvětlivky: *aktivní metabolit DM-3411 
Tab. 3. Vztah mezi dávkou, koncentrací léčiva v plasmě a obsazeností mozkových receptorů (15)

\begin{tabular}{|c|c|c|c|c|c|}
\hline $\begin{array}{l}\text { dávka } \\
\text { brexpiprazolu } \\
\text { mg }\end{array}$ & $\begin{array}{l}\mathbf{C}_{\text {max }} \\
\text { v plazmě } \\
\text { (ng/ml) }\end{array}$ & $\begin{array}{l}\text { \% obsazenost } \\
\text { D2 receptorů }\end{array}$ & $\begin{array}{l}\text { \% obsazenost } \\
\text { D3 receptorů }\end{array}$ & $\begin{array}{l}\text { \% obsazenost } \\
\text { 5HT1A } \\
\text { receptorů }\end{array}$ & $\begin{array}{l}\text { \% obsazenost } \\
\text { 5HT2A } \\
\text { receptorů }\end{array}$ \\
\hline 1 & $47 \pm 8$ & $27 \pm 25$ & $1 \pm 2$ & $28 \pm 10$ \\
\hline 4 & $126 \pm 58$ & $67 \pm 15$ & $31 \pm 8$ & $4 \pm 6$ \\
\hline
\end{tabular}

není substrátem CYP1A2, nemělo by kouření způsobovat významné interakce. Farmakokinetiku brexpiprazolu shrnuje tabulka 2. Tabulka 3 pak prezentuje vztah mezi plazmatickými hladinami a obsazeností vybraných dopaminových i serotoninových receptorů v mozku.

Na vylučování se podílejí i ledviny. Radioaktivně značený brexpiprazol byl zachycen v moči 25 a 46 \% ve stolici. Od středního ledvinového ( $\mathrm{CrCl} \leq 60 \mathrm{ml} / \mathrm{min})$ Či jaterního postižení (Child-Pugh skóre $\geq 7)$ je nutná úprava dávek (viz dále). Brexpiprazol není inhibitorem CYP enzymů ani inhibitorem či substrátem exportních transportérů, jako jsou MDR, P-glykoprotein či BCRP. Expozice (AUC) brexpiprazolu je o 25 \% vyšší u žen než u mužù.

\section{Indikace}

Schválená indikace Evropské lékové agentury je léčba schizofrenie dospělých jedinců. V USA je to navíc ještě prídatná léčba deprese.

\section{Kontraindikace}

Absolutní kontraindikací je přecitlivělost na kteroukoli složku prípravku, která se může projevit např. kopřivkou, angioedémem nebo anafylaxí.

\section{Klinické studie u pacientư se schizofrenií}

Pro ověření účinnosti v léčbě akutní exacerbace schizofrenie byly uspořádány dvě 6týdenní klinické studie fáze 3 (Vector, NCT01396421 a Beacon, NCT01393613), které měly obdobný design. Ve studii Beacon, kde bylo hodnoceno 657 jedinců, byl brexpiprazol v dávkách 2-4 mg (nikoliv 0,25 mg a $1 \mathrm{mg}$ ) účinnější než placebo (16). Ve srovnání s placebem došlo k vyšší redukci na škále pozitivních a negativních příznakư schizofrenie (PANSS) o 8,7, resp 7,6 při dávce 2 mg, resp. 4 mg p. d. Více než 30\% zlepšení v PANSS dosáhlo 48 \% resp. 46 \% pacientů užívajících brexpiprazol 2, resp. 4 mg a 30 \% jedinců na placebu. Počet osob nutných k prokázání léčebného efektu vưči placebu (Number needed to treat - NNT) byl 6-7. Ve studii Vector, kde bylo hodnoceno 623 jedinců, bylo zlepšení ve srovnání s placebem na dávkách brexpiprazolu 1 mg a 4 mg (nikoliv 2 mg). Ve srovnání s placebem došlo k vyšší redukci na škále PANSS o 6,47 bodu při dávce 4 mg p. d. Více než 30\% zlepšení v PANSS dosáhlo 44, resp. 50 \% pacientů užívajících brexpiprazol 1, resp. 4 mg a 32 \% jedinců na placebu (NNT = 6-9) (17).

V Japonsku byla uspořádána 6týdenní studie, která hodnotila účinnost brexpiprazolu 1, 2 a 4 mg v léčbě akutní exacerbace schizofrenie 
( $n=459)$ (18). $V$ této studii pouze jedinci na dávce 2 mg měli statisticky významnou redukci na škále PANSS $(-7,3)$ ve srovnání s placebem. Efekt byl pozorován od 3. týdne studie. Více než 30\% zlepšení v PANSS dosáhlo 25,7 \% pacientů užívajících brexpiprazol 2 mg a 20,4 \% jedinců na placebu (NNT = 19) (18).

Výsledky výše uvedených studií byly předmětem meta-analýzy, která porovnávala efekt brexpiprazolu 2, 4 mg a placeba v léčbě akutní schizofrenie u 1444 pacientů. Obě dávky brexpiprazolu byly významně efektivnější $\checkmark$ redukci celkového skóre PANSS, negativního skóru, frekvenci odpovědi i zlepšení na škále celkového klinického dojmu (CGI). Dávka 2 mg, ale ne 4 mg byla efektivnější pro redukci pozitivních příznakư na škále PANSS. Po odstranění japonské studie byla dávka 4 mg brexpiprazolu účinnější $\checkmark$ redukci pozitivních př́iznakư na škále PANSS. Dávka 2 mg, ale ne 4 mg byla spojena s nižším výskytem vysazení z jakéhokoliv důvodu ve srovnání s placebem (19).

Cílem studie Equator, NCT01668797 bylo ověření prevence relapsu po stabilizaci a v udržovací fázi trvající 52 týdnů (20). Studie byla ukončena předčasně po prokázání účinnosti ve srovnání s placebem na základě interim analýzy. K relapsu došlo u 39 \% pacientů na placebu ve srovnání se $14 \%$ na brexpiprazolu (NNT = 4). Brexpiprazol prokázal lepší kompenzaci př́znaků i funkčních schopností ve srovnání s placebem.

\section{Klinické studie u pacientů s depresivní poruchou}

$\checkmark$ léčbě nepsychotické depresivní poruchy, kde nebylo dosaženo 8týdenní léčbou antidepresivem (fluoxetin, paroxetin, sertralin, duloxetin, venlafaxin) zlepšení stavu 1) o > 50 \% v Montgomery-Åsbergové škály deprese (MADRS) 2) skóre v 17položkové Hamiltonově škále deprese bylo $\geq 14$ a 3) CGI-I bylo $\geq 3$, byl přidán brexpiprazol 2 mg ( $n=175)$ Či placebo ( $n=178)$ k antidepresivu (21). Po 6 týdnech léčby byl rozdíl mezi oběma větvemi léčby vyšší než 3 body $(3,21) \vee$ MADRS ve prospěch brexpiprazolu. Odpovědi na léčbu dosáhlo $23 \%$ pacientů na brexpiprazolu a $16 \%$ na placebu (NNT = 15). Remise bylo dosaženo u $15 \%$ pacientů na brexpiprazolu resp. 9 \% jedinců na placebu (NNT = 17).

$\checkmark$ druhé obdobně uspořádané studii dosáhlo odpovědi na léčbu $23 \%$ pacientů na dávce brexpiprazolu $1 \mathrm{mg}(\mathrm{n}=211)$ a $3 \mathrm{mg}(\mathrm{n}=213)$ ve srovnání se $14 \%$ na placebu $(n=203)(N N T=12)(22)$. Po 6 týdnech léčby byl mezi oběma větvemi léčby detekován statisticky významný rozdíl 1,95 bodu v MADRS ve prospěch brexpiprazolu v dávce 3 mg, nikoliv $1 \mathrm{mg}$. $V$ počtu jedinců dosahujících remise nebylo dosaženo významně lepšího efektu ve srovnání s placebem.

Pacienti s velkou depresivní poruchou, kteří podstoupili během indexové epizody léčbu 1-3 antidepresivy, vstoupili do 8 nebo 10týdenní prospektivní studie, kde byli léčeni placebem přidaným k antidepresivu (23). Jedinci, kteří neodpověděli na léčbu, byli po dobu 6 týdnů léčeni brexpiprazolem 2-3 mg, placebem a kvetiapinem XR 150-300 mg. Přidání brexpiprazolu vedlo k nejvyšší redukci v MADRS ve srovnání s placebem $(-1,48$; Cl -2,56, -0,39), zatímco pridání quetiapinu XR se neodlišovalo od placeba.

V jiné studii, kde nebylo dosaženo 8týdenní otevřenou léčbou antidepresivem zlepšení stavu, bylo porovnáváno ve dvojitě slepém uspořádání přidání brexpiprazolu 1-3 mg k antidepresivu a placebo + antidepresivum po dobu 24 týdnů (24). Primárním cílem studie bylo dosažení remise (MADRS $\leq 10)$ a $\geq 50 \%$ pokles $v$ MADRS od randomizace po dobu alespoň 8 týdnů. V primárním cíli nebyla kombinace s brexpiprazolem $(21,4 \%)$ 
efektivnější než kombinace s placebem (24,9\%). Ani v sekundárním cíli, kterým byla změna MADRS po 6 týdnech léčby, nebylo dosaženo významného rozdílu.

Otevřená studie Aquila měla za cíl zhodnotit dlouhodobou bezpečnost a snášenlivost flexibilních dávek brexpiprazolu jako prídatnou léčbu k antidepresivní léčbě depresivní poruchy u starších dospělých ( $\geq 65$ let) s neadekvátní odpovědí na $\geq 1$ antidepresivum během současné epizody (25). Do studie vstoupilo 132 pacientů a 88 ji dokončilo (66,7 \%). Studie trvala 26 týdnů a probíhala na ambulantních pracovištích ve Spojených státech i Evropě. Všichni pacienti užívali brexpiprazol 1-3 mg denně. Průměrný pokles na škále MADRS od začátku léčby byl 14,5 (standardní chyba 0,9), na škále CGI-S 1,8 (s.ch. 0,1); a v sebeposuzovací škále sociální adaptace 3,2 (s.ch. 0,5).

\section{Další studie}

Dvě studie s brexpiprazolem testovaly jeho podávání po dobu 12 týdnů u agitovaných pacientů u Alzheimerovy demence v dávkách 0,5-2 mg, ale jejich efekt byl srovnatelný s placebem (26). Brexpiprazol byl testován ve fázi II klinického zkoušení u pacientů s ADHD, ale pozitivní efekt nebyl prokázán.

\section{Nežádoucí ú činky u pacientů se schizofrenií}

U pacientůs akutní schizofrenií léčených brexpiprazolem se ve srovnání s nemocnými, kterým bylo podáváno placebo, častěji vyskytovala akatizie (6 \% vs. $5 \%$ ), tremor (3\% vs. $1 \%$ ) a nárůst hmotnosti (4 \% vs. 2 \%) (14). Př́itomnost EPS byla častější na dávce 4 mg ve srovnání s 2 mg brexpiprazolu (19). Prodloužení QTc intervalu 0,3 \% bylo na úrovni placeba 0,5 \% (27), stejně jako hyperprolaktinemie 0,3 vs. 0,2 \% (28).
Při dlouhodobém otevřeném užívání brexpiprazolu (26-52 týdnů), byla nejčastější nespavost 8,6 \%, zvýšení hmotnosti 7,8 \%, bolest hlavy 6,4 \% a agitovanost 5,4 \% (29). Více než 3násobné zvýšení horního limitu hladin prolaktinu z normy bylo zjištěno u 3 \% žen a $1 \%$ mužů (28). Nárůst hmotnosti o > 7 \% byl v dlouhodobých studiích pacientů se schizofrenií zjištěn u $20 \%$ pacientů a naopak snížení o > $7 \%$ u $10 \%$ (14). Změna hmotnosti po 26 týdnech činila v průměru přirůstek $2 \pm 3,4 \mathrm{~kg}$ a po 58 týdnech činil prírůstek 3,2 \pm 7,6 kg (30). Nejčastější prrírůstek hmotnosti o $>7 \%$ v posledních 6 měsících byl zaznamenán u jedinců s BMI < 18,5, kde byl zaznamenán u 60 \% pacientů (30). V dlouhodobých studiích byla změna glykemie, cholesterolu a triglyceridů do zvýšených hladin pozorována u 10\%, 6 \%, resp. $13 \%$ pacientů (14). V dávkách 3× přesahující max. dávku, neprodlužoval brexpiprazol QTc interval (14). Erektilní dysfunkce byla zaznamenána u 0,1\% pacientů (28).

6týdenní studie prokázala nižší výskyt akatizie u brexpiprazolu (9\%) ve srovnání s aripiprazolem (22\%) (8). Analýza aktivujících a sedativních účinků u antipsychotik 2. generace (aripiprazol, asenapin, iloperidon, kariprazin, lurasidon, olanzapin, paliperidon, risperidon, kvetiapin IR a XR, ziprasidon) ukázala, že v této skupině pouze brexpiprazol a paliperidon nevykazují ani sedativní ani aktivační účinky (9).

\section{Nežádoucí účinky u pacientů s depresivní poruchou}

U depresivních pacientů byla častější než při podávání placeba akatizie (9 \% vs. 2 \%), ospalost (5 \% vs. 0,5 \%), nárůst hmotnosti (7 \% vs. 2 \%), úzkost (3 \% vs. $1 \%$ ), tremor a nasopharyngitida (4\% vs. $2 \%)(14)$, snížené libido u (0,6\% vs. 0,2 \%)(31). 
$\checkmark$ dlouhodobých studiích byla změna glykemie, cholesterolu a triglyceridů do zvýšených hladin pozorována u 10 \%, resp. 9\% a 9-13\% pacientů (14). Nárůst hmotnosti o > $7 \%$ byl v dlouhodobých studiích depresivních pacientů pozorován u 30 \%, zatímco snížení hmotnosti o > 7 \% u 4 \%. Prưměrná změna hmotnosti po 26 týdnech činila $+2,9$ kg a po 52 týdnech +3,1 kg (14). Rozdíl v hmotnostním prírůstku po brexpiprazolu ve srovnání s pacienty se schizofrenií je dán jednak kombinací lékư a dále skutečností, že u pacientů s klasickou formou deprese dochází v průběhu onemocnění ke snížení hmotnosti, a zvýšení hmotnosti pak může patřit mezi známky zlepšení stavu. $\vee$ dávkách $4 \times$ přesahující max. dávku v kombinaci s antidepresivy neprodlužoval QTc interval $(32,33)$.

U starších dospělých ( $\geq 65$ let) s neadekvátní odpovědí na $\geq 1$ antidepresivum během současné epizody deprese v otevřené studii Aquila zaznamenala nejvyšší incidenci mezi nežádoucími účinky únava (15\%) a neklid (13\%). Nejčastějším Nú vedoucím k odstoupení ze studie byla únava (3\%). Klinicky významné poruchy hybnosti nebyly zaznamenány (25).

\section{Další nežádoucí účinky}

Brexpiprazol může vést k ortostatické hypotenzi a následně k závratím, tachykardii a vzácně i k synkopě. Toto riziko je obecně nejvyšší na začátku léčby a během titrace dávky. Stejně jako u ostatních antipsychotik je možný výskyt neuroleptického maligního syndromu a tardivních dyskinezí.

Někteři pacienti užívající brexpiprazol, popsali intenzivní nekontrolovatelné nutkání k hraní automatů a neschopnost toto nutkání kontrolovat. Další méně časté nutkání zahrnuje sexuální kompulze, nakupování, přejídání a další impulzivní či kompulzivní chování. V některých případech stačilo snížení dávky, jindy vysazení léku. Protože pacienti nemusí rozpoznat narušenou kontrolu impulzů, je důležité se pacientů a príbuzných ptát na zvýšenou intenzitu či rozvoj nových výše uvedených impulzivních aktů. Tyto přiznaky nejsou specifické pro brexpiprazol, ale byly popsány také po jiných parciálních či ještě častěji po plných agonistech dopaminových D3 receptorů (34).

Animální studie nezaznamenaly známky teratogenity, ale studie u těhotných nebyly provedeny. Animální studie orálního podávání brexpiprazolu ukázaly, že brexpiprazol neovlivňuje mužskou fertilitu, ale snižoval fertilitu samic (27). Nebyly provedeny studie zjištujuící výskyt brexpiprazolu v mateřském mléce. Lék je vylučován do mléka laktujících samic potkanů (27).

\section{Farmakokinetické interakce}

Silní inhibitoři na CYP3A4 (napřr. ketokonazol, claritromycin, grapefruit) či CYP2D6 (např. bupropion, duloxetin, fluoxetin, paroxetin, chinidin) vedou ke zvýšení hladin brexpiprazolu a vyžadují redukci dávky o polovinu, u středně silných inhibitorů o 1/4. Současné podávání brexpiprazolu s CYP3A4 induktory (karbamazepin, třezalka) vyžaduje zvýšení dávek na dvojnásobek (14) až trojnásobek (rifampicin), v tom prípadě je vhodné celodenní dávku rozdělit a podávat $2 \times$ denně, aby nedocházelo ke kolísání hladin (27).

\section{Farmakodynamické interakce}

Informace o farmakodynamických interakcích nejsou dostatečné. Při současném podávání s jinými prípravky je třeba postupovat opatr- 
ně. Brexpiprazol snižuje efektivitu L-dopa a parciálních dopaminových agonistů a jeho použití by se mělo zvážit, pokud benefit z užívání brexpiprazolu převáží riziko snížené účinnosti dopaminergních látek. Protože brexpiprazol blokuje alfa 1 adrenergní receptory, je nutné dát pozor na kombinaci s léky, které blokují alfa 1 adrenergní receptory či s jinými antihypertenzivními léky, protože může dojít k hypotenzi (14).

\section{Dávkování}

V léčbě schizofrenie je doporučena zahajovací dávka první 4 dny 1 mg. Doporučená cílová dávka je 2-4 mg p. d. Titrace pokračuje 5.-7. den 2 mg a dle klinického stavu Ize navýšit na 4 mg od 8. dne léčby. V př́datné léčbě depresivní poruchy či u seniorů je zahajovací dávka 0,5-1 mg $1 \times$ denně. Dávka se zvyšuje v týdenních intervalech do maximální dávky 3 mg. U jedinců se střední až závažnou poruchou jater (Child-Pugh $\geq$ 7) Či středně závažnou a závažnou poruchou ledvin ( $\mathrm{CrCl} \leq 60 \mathrm{ml} / \mathrm{min})$ je maximální dávka 2 mg u pacientů s depresí a 3 mg u pacientů se schizofrenií. U pomalých metabolizérů pro CYP2D6 se doporučuje snížit dávku na polovinu, či až na 1⁄4, pokud je v léčbě používán další lék, který inhibuje CYP3A4.

\section{Plazmatické hladiny, předávkování}

Terapeutické hladiny jsou 40-140 ng/ml, toxická hladina je nad 280 ng/ ml (35). Neexistuje žádné specifické antidotum brexpiprazolu. Aktivní uhlí podané 1 hodinu po podání brexpiprazolu redukovalo $C_{\max }$ o 5-23\% a plochu pod křivkou o 31-39\%. Nejsou k dispozici údaje o hemodializovatelnosti léčiva.

\section{Souhrn}

Brexpiprazol prokázal efektivitu v akutní i udržovací léčbě schizofrenie. Mezi parciálními D2 agonisty byl nejlepší v dosažení odpovědi na léčbu, protože dosáhl nejnižší NNT = 7 (pokles v PANSS > 30 \%) ve srovnání s aripirazolem NNT $=8$ a kariprazinem NNT $=11(4)$. Brexpiprazol rozšiřuje skupinu parciálních agonistů dopaminu, které jsou oblíbenou podskupinou antipsychotik zejména pro výbornou snášenlivost, čímž posouvají uživatelskou kvalitu a komfort antipsychotik. Snášenlivost je dána především nízkým výskytem EPS, sedace, metabolických i sexuálních nežádoucích účinků, hyperprolaktinemie či prodloužení QTc intervalu ve srovnání s většinou antagonistů dopaminu. Porovnání s aripiprazolem ukazuje nižší výskyt akatizie i insomnie při léčbě brexpiprazolem $(8,9)$, což potvrzuje predpoklady ohledně nižší vnitřní aktivity brexpiprazolu na D2 receptorech a dává dobré vyhlídky ke snášenlivosti u afektivních poruch. Uživatelsky př́ijemné antipsychotikum, které je podáváno 1X denně, je dobrým výchozím predpokladem pro dobrou adherenci, jenž je základem úspěchu dlouhodobé léčby schizofrenie. Prevence relapsu bylo dosaženo ve srovnání s placebem u každého čtvrtého pacienta (NNT = 4), což je pro per orální antipsychotikum výborný výsledek. Lepší NNT pro udržení remise než dosažení odpovědi v akutní léčbě naznačuje, že síla brexpiprazolu bude více v udržovací než akutní léčbě floridních pacientů.

Přídatný efekt brexpiprazolu k antidepresivu v léčbě nepsychotické resistentní deprese není tak robustní jako efekt antipsychotický. Zde je NNT pro odpověd' na léčbu u brexpiprazolu numericky vyšší NNT = 11 ve srovnání s aripirazolem NNT = 7 (36), ale protože se jejich intervaly jistoty překrývají, není převaha jednoznačná. Ve srovnání 
Tab. 4. Indikace dle FDA pro parciální dopaminové antagonisty, upraveno dle (37)

\begin{tabular}{|c|c|c|c|}
\hline & aripiprazol & brexpiprazol & kariprazin \\
\hline schizofrenie dospělých & $\checkmark$ & $\checkmark$ & $\checkmark$ \\
\hline schizofrenie adolescentů & $\checkmark$ & & \\
\hline $\begin{array}{l}\text { bipolární porucha (dospělých a dětí), } \\
\text { akutní monoterapie manie }\end{array}$ & $\checkmark$ & & \\
\hline bipolární porucha (dospělých a dětí), přídatná léčba k lithiu či valproátu & $\checkmark$ & & \\
\hline bipolární porucha, akutní léčba manických či smíšených epizod dospělých & $\checkmark$ & & $\checkmark$ \\
\hline bipolární porucha, depresivní epizoda & & & $\begin{array}{c}\text { 9/2018 prijijato ke } \\
\text { schvalovacímu procesu FDA }\end{array}$ \\
\hline bipolární porucha, udržovací léčba dospělých & $\checkmark$ & & \\
\hline přídatná léčba velké depresivní poruchy dospělých & $\checkmark$ & $\checkmark$ & \\
\hline Tourettův syndrom dětí & $\checkmark$ & & \\
\hline iritabilita dětí spojena s poruchou autistického spektra & $\checkmark$ & & \\
\hline
\end{tabular}

s aripiprazolem měl brexpiprazol u této populace méně akatizie (počet potřebný k poškození (number needed to harm) NNH = 5 vs. 15) a nárůstu hmotnosti (NNH = 22 vs. 52), ale více ospalosti (NNH = 54 vs. 34). Když do celkového hodnocení léčby zahrneme nežádoucí účinky, pravděpodobnost pro odpověd' na léčbu vs. přerušení pro nežádoucí účinky je vyšší u brexpiprazolu $(4,5)$ než aripiprazolu $(3,6)$ (36). Lze predpokládat další klinické testování brexpiprazolu v indika- cích, kde byl úspěšný aripiprazol či kariprazin (Tab. 4). Terapeutický potenciál brexpiprazolu může být v budoucnu širší, než je dosud prokázáno. Teprve další výzkum a praxe ukáží místo brexpiprazolu mezi antipsychotiky.

Tato publikace vznikla v rámci projektu LO1611 za finanční podpory MŠMT v rámci programu NPU I. 


\section{LITERATURA}

1. Češková E. Postavení aripiprazolu v klinické praxi. Čes a slov Psychiatrie 2011; 107: 110-114. 2. Mohr P, Kopeček M, Brunovský M, et al. Kariprazin in Klinická psychofarmakologie.Maxdorf, 2017, pp 161-164.

3. Ceskova E, Silhan P. Novel treatment options in depression and psychosis. Neuropsychiatr Dis Treat 2018; 14: 741-747.

4. Citrome $L$. The $A B C$ 's of dopamine receptor partial agonists - aripiprazole, brexpiprazole and cariprazine: the 15-min challenge to sort these agents out. Int J Clin Pract 2015; 69: 1211-1220. 5. Maeda K, Sugino H, Akazawa $H$, et al. Brexpiprazole l: in vitro and in vivo characterization of a novel serotonin-dopamine activity modulator. J Pharmacol Exp Ther 2014; 350: 589-604. 6. Mohr P, Kopeček M, Brunovský M, et al. Brexpiprazol, in Klinická psychofarmakologie. Maxdorf, 2017, pp 135-138.

7. Stahl SM. Mechanism of action of brexpiprazole: comparison with aripiprazole. CNS Spectr 2016; 21:1-6.

8. Citrome L, Ota A, Nagamizu K, et al. The effect of brexpiprazole (OPC-34712) and aripiprazole in adult patients with acute schizophrenia: results from a randomized, exploratory study. Int Clin Psychopharmacol 2016; 31: 192-201.

9. Citrome L. Activating and Sedating Adverse Effects of Second-Generation Antipsychotics in the Treatment of Schizophrenia and Major Depressive Disorder. Absolute Risk Increase and Number Needed to Harm. J Clin Psychopharmacol 2017; 37: 138-147.

10. Stoner SC. Management of serious cardiac adverse effects of antipsychotic medications Ment Health Clin 2017; 7: 246-254.

11. Polcwiartek C, Sneider B, Graff C, et al. The cardiac safety of aripiprazole treatment in patients at high risk for torsade: a systematic review with a meta-analytic approach. Psychopharmacology (Berl) 2015; 232: 3297-3308.

12. Chattopadhyay A, Frey S,Green G. Bifeprunox versus placebo for schizophrenia. Cochrane Database Syst Rev 2016; 10: CD012029.

13. Maeda K, Lerdrup L, Sugino H, et al. Brexpiprazole II: antipsychotic-like and procognitive effects of a novel serotonin-dopamine activity modulator. J Pharmacol Exp Ther 2014; 350 605-614.

14. Rexulti (brexpiprazole) [product information]. Tokyo, Japan: Otsuka Pharmaceutical Co, Ltd 2015.

15. I. OPDC: PET Trial to Assess the Receptor Occupancy of Brexpiprazole in Adult Subjects With Schizophrenia. [cited 2018 Nov 11]. Available from: http://dinicaltrials.gov/show/NCT01854944 16. Correll CU, Skuban A, Ouyang J, et al. Efficacy and Safety of Brexpiprazole for the Treatment of Acute Schizophrenia: A 6-Week Randomized, Double-Blind, Placebo-Controlled
Trial. Am J Psychiatry 2015; 172: 870-880

17. Kane JM, Skuban A, Ouyang J, et al. A multicenter, randomized, double-blind, controlled phase 3 trial of fixed-dose brexpiprazole for the treatment of adults with acute schizophrenia. Schizophr Res 2015; 164: 127-135.

18. Ishigooka J, Iwashita S,Tadori Y. Efficacy and safety of brexpiprazole for the treatment of acute schizophrenia in Japan: A 6-week, randomized, double-blind, placebo-controlled study. Psychiatry Clin Neurosci 2018; 72: 692-700

19. Kishi T, Oya K, Matsui Y, et al. Comparison of the efficacy and safety of 4 and 2 mg/day brexpiprazole for acute schizophrenia: a meta-analysis of double-blind, randomized placebo-controlled trials. Neuropsychiatr Dis Treat 2018; 14: 2519-2530.

20. Fleischhacker WW, Hobart M, Ouyang J, et al. Efficacy and Safety of Brexpiprazole (OPC 34712) as Maintenance Treatment in Adults with Schizophrenia: a Randomized, Double-Blind, Placebo-Controlled Study. Int J Neuropsychopharmacol 2017; 20: 11-21.

21. Thase ME, Youakim JM, Skuban A, et al. Efficacy and safety of adjunctive brexpiprazole $2 \mathrm{mg}$ in major depressive disorder: a phase 3, randomized, placebo-controlled study in patients with inadequate response to antidepressants. J Clin Psychiatry 2015; 76: 1224-1231.

22. Thase ME, Youakim JM, Skuban A, et al. Adjunctive brexpiprazole 1 and 3 mg for patients with major depressive disorder following inadequate response to antidepressants: a phase 3, randomized, double-blind study. J Clin Psychiatry 2015; 76: 1232-1240.

23. Hobart M, Skuban A, Zhang P, et al. A Randomized, Placebo-Controlled Study of the Efficacy and Safety of Fixed-Dose Brexpiprazole $2 \mathrm{mg} / \mathrm{d}$ as Adjunctive Treatment of Adults With Major Depressive Disorder. J Clin Psychiatry 2018; 79.

24. Bauer $M$, Hefting $N$, Lindsten A, et al: A randomised, placebo-controlled 24-week study evaluating adjunctive brexpiprazole in patients with major depressive disorder. Acta Neuropsychiatr 2018; $1-9$.

25. Lepola U, Hefting N, Zhang D, et al. Adjunctive brexpiprazole for elderly patients with major depressive disorder: An open-label, long-term safety and tolerability study. Int J Geriatr Psychiatry 2018; 33: 1403-1410.

26. Otsuka Pharmaceutical Development \& Commercialization I. A study of two fixed-doses of brexpiprazole in the treatment of subjects with agitation associated with dementia of the Alzheimer's type [Internet] Bethesda (MD): National Library of Medicine (US); 2000 [cited 2018 Nov 11]. Available from: http://clinicaltrials.gov/show/NCT01862640;

27. Rexulti, brexpiprazole (summary of product characteristics). the European Medicines Agency http://www.ema.europa.eu. 2018. 
28. Ivkovic J, Lindsten A, George V, et a. Effect of Brexpiprazole on Prolactin: An Analysis of Short- and Long-Term Studies in Schizophrenia. J Clin Psychopharmacol 2019; 39: 13-19. 29. Forbes A, Hobart M, Ouyang J, et al. A Long-Term, Open-Label Study to Evaluate the Safety and Tolerability of Brexpiprazole as Maintenance Treatment in Adults with Schizophrenia. Int J Neuropsychopharmacol 2018; 21: 433-441.

30. Newcomer JW, Eriksson H, Zhang P, et al. Changes in metabolic parameters and body weight in brexpiprazole-treated patients with acute schizophrenia: pooled analyses of phase 3 clinical studies. Curr Med Res Opin 2018; 34: 2197-2205.

31. Otsuka America Pharmaceutical I. Data on file (REX-024). Safety Profile for REXULTI (brexpiprazole) as Adjunctive Treatment in MDD, 2018. [cited 2019 Jan 14]. Available from: https://www.rexultihcp.com/mdd/safety

32. Markovic M, Gallipani A, Patel KH, et al. Brexpiprazole. Ann Pharmacother 2017; 51: 315-322. 33. Diefenderfer $L A$,luppa $C$ : Brexpiprazole. A review of a new treatment option for schi- zophrenia and major depressive disorder. Ment Health Clin 2017; 7: 207-212.

34. Moore TJ, Glenmullen J,Mattison DR. Reports of pathological gambling, hypersexuality, and compulsive shopping associated with dopamine receptor agonist drugs. JAMA Intern Med 2014; 174: 1930-1933.

35. Hiemke C, Bergemann N, Clement HW, et al. Consensus Guidelines for Therapeutic Drug Monitoring in Neuropsychopharmacology: Update 2017. Pharmacopsychiatry 2018; 51: 9-62. 36. Citrome L. Brexpiprazole for schizophrenia and as adjunct for major depressive disorder: a systematic review of the efficacy and safety profile for this newly approved antipsychotic - what is the number needed to treat, number needed to harm and likelihood to be helped or harmed? Int J Clin Pract 2015; 69: 978-997.

37. Frankel JS,Schwartz TL. Brexpiprazole and cariprazine: distinguishing two new atypical antipsychotics from the original dopamine stabilizer aripiprazole. Ther Adv Psychopharmacol 2017; 7: 29-41. 